\title{
One Point Technique of Intracutaneous Sterile Water Injection is as Effective as Four Points Technique in the Management of Labor Pain
}

\section{Teknik Satu Titik Injeksi Air Steril Intrakutan sama Efektifnya dengan Teknik Empat Titik dalam Penanganan Nyeri Persalinan}

\author{
Taufik Ismail, ${ }^{1}$ Sonny Sasotya, ${ }^{1}$ Adhi Pribadi, ${ }^{1}$ Erwin Pradian $^{2}$ \\ ${ }^{1}$ Department of Obstetrics and Gynecology \\ ${ }^{2}$ Department of Anesthesiology \\ Faculty of Medicine University Padjadjaran/ \\ Dr. Hasan Sadikin Hospital \\ Bandung
}

\begin{abstract}
Objective: To compare the score of VAS (visual analog scale), length of labor, and APGAR score in intracutaneous sterile water injection between one point technique and four points technique at Michaelis Rhomboid area in management of labor pain.

Method: This is an experimental study, subjects were included by blinded controlled randomized study on 50 women with term pregnancy stage I active phase and were planned for spontaneous delivery. Subjects were divided into 2 groups randomly, 25 women with $0.5 \mathrm{ml}$ sterile water intracutaneous injection on 4 points and 25 women with that on 1 point injection at one site at the painful area. Result: Reduction of labor pain on 1-point technique could decrease VAS score the most, 85.4 (4.3) into 48.4 (8.5) on minute 10. Length of labor was 11.2 (1.15) on 1 point injection group compared to 11.4 (1.2) on those with 4 point injection. On the other hand, APGAR score of the baby on group having 1-point injection was $7.86(0.5)$ on min 1 and $9.68(0.5)$ on min 5, compared to that on 4-points injection group, $7.52(0.7)$ and $9.56(0.5)$, respectively. In addition, $60 \%$ felt uncomfortable with 1 -point injection whereas $80 \%$ of patients felt uncomfortable in 4-points injection.
\end{abstract}

Conclusion: There is no significant difference on reduction of VAS score, duration of labor, and APGAR score of the baby between the group having 1 point injection and 4-point injection. However, injection on 1 point is more comfortable.

[Indones J Obstet Gynecol 2012; 36-4: 167-70]

Keywords: APGAR, intracutaneous sterile water injection, length of labor, VAS

\begin{abstract}
Abstrak
Tujuan: Mengetahui perbandingan skor visual analog scale (VAS), lamanya persalinan dan nilai appearance, pulse, grimace, activity, respiration (APGAR) antara injeksi air steril intrakutan pada satu titik dengan empat titik pada daerah Michaelis Rhomboid dalam penanganan nyeri persalinan.

Metode: Penelitian ini bersifat eksperimental dengan melakukan uji klinis acak terkontrol buta tunggal terhadap 50 perempuan hamil cukup bulan yang berada dalam kala I fase aktif dan direncanakan menjalani persalinan spontan. Subjek dibagi menjadi 2 kelompok perlakuan secara acak, 25 orang mendapat injeksi air steril intrakutan $0,5 \mathrm{ml}$ sebanyak 4 titik di daerah Michaelis Rhomboid dan 25 orang lainnya mendapat injeksi air steril intrakutan 0,5 $\mathrm{ml}$ di 1 titik pada daerah yang paling dirasakan nyeri di daerah pinggang belakang.

Hasil: Penurunan rasa nyeri persalinan pada teknik 1 titik dapat menurunkan skor VAS paling banyak dari $85,4(4,3)$ menjadi $47,6(7,2)$ dibandingkan dengan teknik 4 titik yaitu 84,6(4,3) menjadi 48,4(8,5) pada menit ke 10. Perbandingan lamanya persalinan pada kelompok injeksi 1 titik rata-rata 11,2(1,15) dibandingkan dengan teknik 4 titik 11,4(1,2). Sementara itu nilai APGAR bayi pada kelompok injeksi 1 titik 7,86(0,5) pada menit ke 1 dan 9,68(0,5) pada menit ke 5 dibandingkan dengan injeksi 4 titik 7,52(0,7) pada menit ke 1 dan 9,56(0,5) pada menit ke 5. Selain itu untuk persentase kenyamanan didapatkan untuk teknik injeksi 1 titik 60\% menyatakan kurang nyaman dan 40\% nyaman. Sedangkan untuk teknik 4 titik 80\% kurang nyaman dan 20\% tidak nyaman.
\end{abstract}

Kesimpulan: Tidak ada perbedaan bermakna penurunan skor VAS, lama persalinan dan nilai APGAR bayi yang dilahirkan. Namun dari segi kenyamanan, teknik injeksi 1 titik lebih baik.

[Maj Obstet Ginekol Indones 2012; 36-4: 167-70]

Kata kunci: APGAR, lama persalinan, suntikan air steril intrakutan, VAS

Correspondence: Taufik Ismail, Faculty of Medicine University Padjadjaran/Dr. Hasan Sadikin Hospital Bandung Jln. Pasteur 38 Bandung. Telephone: 022-2032530. Fax: 022-2039086. Telephone: 08112214245. Email: taufik810@yahoo.com

\section{INTRODUCTION}

Labor pain is a response of nerve stimuli caused by uterine contraction and tissue damage during delivery process. Perception and intensity of pain influence physiological condition of the patient, delivery process, and fetal condition. ${ }^{1}$
Labor pain could induce anxiety, hyperventilation, increase blood pressure, and reduce bowel and bladder motility. ${ }^{2-6}$ Some events contribute into pain labor during active phase on stage I are hypoxia of uterine muscle, lactic acidosis, distension of lower segment of the uterine, stretching of 
the ligaments, and compression of the bony pelvic. The pain was induced by stimulation of afferent $C$ nerve ending that come from uterine corpus and cervix, and this nerve fiber end at dorsal horn of spinal segment T10 up to L1 and induce visceral pain that referred to back flank. ${ }^{7}$ This condition will increase catecholamine that induce disregulation of uterine contraction thus induce uterine hypotonic inertia, prolonged labor, and fetal well being. 8

Sterile water intracutaneous injection on 4 points procedure at lumbosacral area is an easy and well studied to decrease visceral pain. ${ }^{9}$ This technique was simple, inexpensive, has minimal side effect, and could be given by general physician. ${ }^{10-12}$

One of the side effects of sterile water injection is inducing localized sharp pain on injection site that last for 20-30 sec. This method was not recommended by some women because the injection induced somatic pain and cause uncomfortable condition. ${ }^{13}$

We try to compare the technique with 4 points injection site and one point injection site at Michaelis Rhomboid area to check for VAS score, length of labor, and APGAR score of the baby. One point injection might give clinical improvement and comfort to the patient. In addition, one point injection technique could reduce staff number that performing the procedure and minimize the time needed to perform the procedure. ${ }^{14}$

\section{METHOD}

\section{Subjects and Methods}

This study was a single blind randomized controlled trial. The subject was 50 primigravida with aterm pregnancy on active phase of labor and planned for spontaneous delivery. Subjects were divided into 2 groups randomly, 25 women received sterile water injection at 4 points at Michaelis Rhomboid area whereas another 25 women received one point injection at the most painful area at the back flank. VAS score was evaluated at delivery room, vital sign, and other physical examination was performed to determine the dilation of the cervix and labor progress. In addition, fetal well-being was also analyzed. The midwives performed the procedure when the uterine con- tracted. The midwives got an explanation about the procedure before and they received a closed envelope explaining the type of injection they should perform. The patient was postioned in the sitting position as to give good access for the midwife to do the injection. For group A (one point injection), it should first be asked where is the most painful area at the back flank. If the patient couldn't point out the exact position because of referred pain, the injection was performed at the center Michaelis Rhomboid area. Injection was performed quickly during contraction until it formed a small blister on the skin. Group B (4 points injection), was injected at the Michaelis Rhomboid area and injection was performed by 2 midwives on the same time during uterine contraction. The patient was then evaluated for VAS score on minute $10,30,60$, 90 , and 120 by the researcher. Other examination such as vital sign, progress of labor and fetal wellbeing was done according to the requirement. The result was then recorded. In addition, secondary data was also recorded on 1 day post partum, such as patient satisfy to the analgesic effect of the injection, the comfort during procedure, and also patient perspective for the same procedure for the next delivery.

\section{Data Analysis}

The result of VAS score, length of labor and APGAR score of both groups was analyzed using t-test, chi square, and Mann Whitney test (significant if $\mathrm{p}<0.05$ ).

\section{RESULT}

In this study, we obtained mean value of VAS score in the two groups, which was showed in Table 1.

Table 1. VAS Score Comparison between 2 Groups

\begin{tabular}{cccc}
\hline \hline Time & $\begin{array}{c}\text { One Point } \\
\text { Group } \\
\mathbf{n = 2 5}\end{array}$ & $\begin{array}{c}\text { Four Points } \\
\text { Group } \\
\mathbf{n}=\mathbf{2 5}\end{array}$ & $\mathbf{p}$ \\
\hline VAS before Inj. & $85.40(4.31)$ & $84.60(4.31)$ & 0.509 \\
VAS 10 minute & $47.60(7.23)$ & $48.40(8.50)$ & 0.670 \\
VAS 30 minute & $40.80(3.12)$ & $40.20(3.67)$ & 0.494 \\
VAS 60 minute & $40.60(3.00)$ & $39.80(4.20)$ & 0.465 \\
VAS 90 minute & $41.20(3.32)$ & $40.60(5.07)$ & 0.568 \\
VAS 120 minute & $46.00(6.45)$ & $46.60(7.73)$ & 0.711 \\
\hline \hline
\end{tabular}

Note : Mann Whitney formula, Significant $p<0.05$ 
Table 1 showed that all of the variable has $p$ value $>0.05$, which is insignificant. The result showed that there is no significant difference between one point injection and 4 points injection group on VAS score before until 120 min after injection.

Table 2. The Comparison of the Length of Labor between 2 Groups

\begin{tabular}{lccc}
\hline \hline & $\begin{array}{c}\text { One Point } \\
\text { Group } \\
\mathbf{n = 2 5}\end{array}$ & $\begin{array}{c}\text { Four Points } \\
\text { Group } \\
\mathbf{n = 2 5}\end{array}$ & $\mathbf{p}$ \\
\hline Lenght of Labor & $11.21(1.15)$ & $11.40(1.17)$ & 0.595 \\
\hline \hline
\end{tabular}

Note: Mann Whitney formula, Significant $p<0.05$

Table 2 shows that, there's no significant difference in the length of labor between 1 site injection group and 4 site injection.

Table 3. Comparison of APGAR Score between 2 Groups

\begin{tabular}{cccc}
\hline \hline & $\begin{array}{c}\text { One Point } \\
\text { Group } \\
\mathbf{n = 2 5}\end{array}$ & $\begin{array}{c}\text { Four Points } \\
\text { Group } \\
\mathbf{n = 2 5}\end{array}$ & $\mathbf{p}$ \\
\hline APGAR 1 minute & $7.68(0.48)$ & $7.52(0.65)$ & 0.446 \\
APGAR 5 minute & $9.68(0.48)$ & $9.56(0.51)$ & 0.387 \\
\hline \hline
\end{tabular}

Note : Mann Whitney formula, Significant $p<0.05$

Table 3 shows that there's no significant difference between the length of labor in 1 site injection group and 4 site injection in APGAR one minute and APGAR five minute.

Secondary data shows that in the one site injection group, $60 \%$ of the patients felt less comfortable and $40 \%$ felt comfortable. On the other hand, in the four sites injection group, $80 \%$ felt less comfortable and $20 \%$ felt uncomfortable, showing that no patients in this group felt comfortable. Mean while, the patient's satisfaction from the decreasing pain in the one site injection group was $100 \%$, and in the four sites injection group was $96 \%$. We also found that in both groups, all patients wished to have the same procedure for the next labor.

\section{DISCUSSION}

This study showed that there was no significant difference in reduction of VAS score between group received 1-point sterile water subcutaneous injec- tion and those who received four points injection. Both of these techniques gave adequate analgesia effect. Interruption of pain route is the final result we expected. Michaelis Rhomboid area is the location suggested for injection, because in this location the pain was felt the most intense during labor. In this perspective, it was known that hyperstimulation of the skin can cause changes of perception visceral agent and this mechanism can change the referred pain into referred analgesia. When the sterile water is injected under the skin it may cause small bubble or papule which cause local irritation and strong stimuli on nosiceptor about 30 second. Analgesia cause by this irritation on function gate in medula spinalis level and a quite important factor to a successful therapy. ${ }^{12,15}$ Research on Iran say that gate control theory may explain analgesia effect by injection sterile water that can cause pain inhibition to medula spinalis, but because the effect only occurred on 1 segment then this study suggest that there is an involvement of non specific pain modulation. ${ }^{16}$ There is a system in human body which endogenously inhibit pain. To date, our experience regarding body system that can inhibit pain is still not well understood. A very painful stimulus will activate central pain inhibitory system's production from endogen opioids. Signals from the sensor in pain area will go through ascending pathway to the brain. Those signals will stimulate area on periaqueductal grey matter, which will produce $\beta$-endorphin and neurotensin and also stimulate great raphe nucleus to produce noradrenalin and serotonin. Those substances will go through descending pathway back to dorsal horn and will inhibit transmission on nociceptive in medulla spinalis level. ${ }^{17-18}$ Other mechanism is counter-irritation mechanism. According to Melzack there is a phenomenon in which a pain stimulus can reduce other pain cause by other stimulus. Research on Iran and Sweden pictured a diffuse concept of noxious inhibitory control (DNIC) which is a physiologic mechanism that explain this counter-irritation mechanism. DNIC is a process that inhibits multiple neuron on dorsal horn of medula spinalis, in which pain stimulus is sent on part of the body but far from it's reception zone. The result will be less pain on the far side. This will support the method of injecting sterile water on laboring woman. ${ }^{16,15,19}$

Our study showed that there is no significant difference between 4-site technique and 1-site technique on length of labour and APGAR score of the 
infant. To note there is a lot of factor that may affect the progress and length of labor and APGAR score of the baby. Many researches have shown that intracutaneous sterile water injection is a safe and effective alternative to reduce labor pain. Although it is not a primary option to reduce pain, but most of the patients receiving the procedure showed positive attitude and decrease in pain immediately after administration of the injection.

From this study it was found that there was $60 \%$ subjects who felt less comfortable in the group receiving 1-point technique and $80 \%$ in the group receiving 4-point technique injection. However, there were 10 subjects $(40 \%)$ in the group receiving 1-point injection who expressed comfort, while no one in the other group expressed similar feeling. In addition, it was found that all patients who received 1 site injection were satisfied with the method of analgesia provided. Meanwhile in the other group, there was one person who expressed dissatisfaction regarding the pain felt during the procedure and brief analgesia effects.

Other positive responses were the desire to receive the same method in the next delivery procedure in all patients in both groups.

\section{CONCLUSION}

In conclusion, there are no significant differences in terms of reduction in VAS score, duration of labor and APGAR score of the babies born from the mothers who has received sterile water intracutaneous injection technique either in 1 site or 4 sites. But in terms of comfort, one sites techniques was better than the 4 sites technique.

\section{REFERENCES}

1. Mulyata ST. Pendekatan psikologis dapat berperan sebagai analgesi nyeri persalinan Tesis. Surakarta: Bagian Anestesi dan Reanimasi Fakultas Kedokteran Universitas Negeri Surakarta/RSUD Dr. Moewardi. 2004: 251-60.
2. Reeder SJ. Maternity nursing, family, new born and women's health care. $18^{\text {th }}$ Ed. Philadelphia: Lippincott 1997: 573-616.

3. Lowe N. The nature of labor pain. Am J Obstet Gynecol. 2002; 186(5):16-24.

4. Camann W, Ostheimer G. Physiology adaptations during pregnancy. Int Anesthesiol Clin. 1990; 28:2-10.

5. Huch R. Maternal hyperventilation and the fetus. J Perinatal Med. 1986; 14(1):3-7.

6. Hagerdal M, Morgan C, Sumner A, Gutsche B. Minute ventilation and oxygen consumption during labor with epidural analgesia. Anesthesiology. 1983; 59(5):425-7.

7. Bonica JJ, McDonald JS. The pain of childbirth. In: Bonica JJ, ed. The management of pain. $2^{\text {nd }}$ Ed. Philadelphia: Lea \& Febiger; 1995: 243-73.

8. Wiruchpongsanon P. Relief of low back labor pain by using intracutaneous injection of steril water: a randomized clinical trial. J Med Assoc Thai. 2006; 89(5):571-6.

9. Hutton E, Kasperink M, Rutten M, Reitsma A, Wainman B. Sterile water injection for labor pain: a systematic review and meta-analysis of randomized controlled trial. BJOG. 2009; 116(9):1158-66.

10. Huntley A, Coon J, Ernst E. Complementary and alternative medicine for labor pain: a systematic review. Am J Obstet Gynecol. 2004; 19(1):36-44.

11. Reynold J. Intracutaneous sterile water for back pain in labor. Can Fam Physician. 1994; 40:1785-92.

12. Ader L, Hansson B, Wallin G. Parturition pain treated by intracutaneous injection of sterile water. Pain. 1990; 41(2): 133-8.

13. Peart K. Managing labor pain safely. Aust J Adv Nurs. 2006;25:43-8.

14. Saxena K, Nischal H, Batra S. Intracutaneous injections of sterile water over the sacrum for labor analgesia. Indian J Anesth. 2009;53(2):169-73.

15. Bonica JJ. Peripheral mechanism and pathway of parturition pain. Br J Anesth. 1979;51(1):53-9.

16. Bahasadri S, Ahmadi AS, Dehghani NM, Habibi GR. Subcutaneous sterile water injection for labour pain: a randomized controlled trial. Aust NZ J Obstet Gynecol. 2006; 46(2):102-6.

17. Morgan GF, Mikhail MS, Munay MJ. Clinical anesthesiology. $4^{\text {th }}$ Ed. New York: McGraw-Hill; 2006:359-411.

18. Pertovaara A, Almeida A. Endogenous pain modulation: descending inhibitory systems. In: Cervero F, ed. Handbook of clinical neurology. Philadelphia: Elsevier. 2006:179-92.

19. Le Bars D, Villanueva L, Willer J, Bouhassira D. Diffuse noxious inhibitory controls (DNIC) in animals and in man. Acupunct Med. 1991; 9(4):47-56. 